\title{
The Codification of Islamic Criminal Law in the Sudan: Penal Codes and Supreme Court Case Law Under Numayrī and al-Bashïr
}

\author{
Olaf Köndgen
}

Leiden: Brill, 2017. 480 pages.

This meticulous work covers the history of legislation during two eras of military juntas in the Sudan: that of Numayrī, who led a coup against the democratic government and ruled from May 1969-April 1985, and of Bashir, who also came to power through a military coup and ruled the country from 1989-2018. This book was published just one year before a popular uprising brought down Bashir's government. In his search to uncover the politics around Islamic codes, Köndgen used both primary and secondary sources, including court cases he closely reviewed, as well as interviews with lawyers and judges. This book is the most extensive study on the recent Islamic laws in the Sudan.

The strong link between the two eras under consideration here is that both were military regimes that claimed Islam as the main source for legislation. Numayri claimed it when his government was ailing and he thought proclaiming sharía as the source of all legislation would be a means to hold on to his dictatorship. Two years after declaring sharia the law of the land his government was overthrown by a popular uprising that ensued because of the injustices done in the name of Islam. For his part, al-Bashir staged a 
military coup with strong support from his base (the Islamic Movement) and overthrew the short-lived democracy (1985-1989). He immediately declared what he said was a "full-bodied" Islamist agenda.

The book is divided into thirteen chapters, including an introduction and a conclusion. In addition, it includes a glossary of Arabic legal terms, references, Sudanese laws and legislative projects, a list of Supreme Court cases, and an index of people and places and an index of subjects and terms.

Chapter one is a much needed introduction for anyone who is not familiar with the sources and what it takes to research such topics in the Sudan. Chapter two offers a short history of Islamic laws in the Sudan since the Sultanate of Sinnar (rn. 16th-18th century). This history shows people's intolerance for unjust laws, even when they are labeled Islamic or sharia-based. In chapter three the author presents the sources, procedures, evidence law, and the general principles of Sudanese Islamic criminal law.

The next seven chapters are dedicated to the seven major crimes in Sudanese criminal law, namely, adultery, slander, dealing in or consuming alcohol, theft, highway robbery, apostasy, and homicide and bodily injury. These crimes have, by and large, the harshest punishments in sharia. The book covers punishments from discretional ( $\left.t a^{i} z i r\right)$ measures to capital punishment.

These chapters are similarly organized. The author explains the legislation techniques and implementation of the law governing the above crimes during the reigns of Numairy and Bashir. He starts with a discussion of fiqh (Islamic jurisprudence) followed by discussion of the specific crime in both the 1983 Penal Code and the 1991 Criminal Law, followed by court cases (especially Supreme Court decisions) that have interpreted those laws. On many occasions the Supreme Court succeeded in alleviating the harshness or earlier interpretations conducted by the lower courts.

Köndgen's discussion of hadd theft (sariqa haddiyya) in chapter seven serves as a good example of his methodological approach. He considers how the law was applied in 1983 and 1991; he discusses what constitutes theft in the various juristic opinions and what punishment should be imposed when the act is proven through the exacting proof requirements of a hadd crime. Köndgen points out the legal uncertainties (shubuhät) established by fiqh. He then moves to investigate whether the hadd punishment, that is, amputation of the right hand, may be averted by discovering a legal uncertainty (shubha) that precludes the hadd. His reading of court cases 
rounds out the chapter, offering the reader a comprehensive and nuanced analysis of each crime within Sudanese law.

Köndgen appreciates other factors that impinge upon the interpretation and implementation of shari'a laws. One common factor in both eras (if more vicious under Bashir) was the Security Bureau, which had more authority than any other law enforcement agency. Köndgen traces how this oppressive body manipulated religion to politics. As such, the adoption of sharía never was purely about the making of a religious state. As the author notes, Sudanese law is an admixture of postcolonial laws and sharía. The tactic of adopting shari'a to prevent popular unrest did not work for either era. Sudanese Muslims believe that Islam is justice; the injustices that marked so-called Islamic laws was a main cause in opposing each regime.

The book further considers some of the cases that attracted international attention, such as Sudan Government v. Mahmoud Mohamed Taha. Taha was tried and executed for apostasy in 1983, despite the fact that the Islamic Penal code of 1983 did not include such a crime. Judges used Article 3 of the Basic Rules of Judgment Act, "which made a decision based on the Qur'an and Sunna possible, even if there was no legislative text" (67). This was done despite Article 70 of the 1973 constitution adopted by Numayri's era and Article 34(4) in the 2005 constitution that prevented the retrospective application of laws. Ignoring the constitution was typical, as if constitutions were made to be broken. The disregard of the law continued when the judicial process of appeal was neglected for political purposes. In the trial of Lalitt Ratnalal Shah, a businessman of Indian origin, the three stages of adjudication (the First Instance Court, Appeal Court, and Supreme Court) included the same judges (67)!

The organization of this book, its theoretical nuance, and its attention to case law make it one of the best publications on Islam in Sudan. One hopes for its translation into Arabic in order that it gain a wide readership.

Asma M. Abdel Halim Associate Professor, Women's and Gender Studies University of Toledo, Toledo, $\mathrm{OH}$

doi: 10.35632/ajis.v37i1-2.853 